\title{
Critical performativity for a decolonising curriculum: Possibilities in creating emancipatory classroom spaces for exploring alternative knowledge frames
}

\section{Sadi Seyama}

Department of Education Leadership and Management, Faculty of Education, University of Johannesburg, Johannesburg, South Africa

sseyama@uj.ac.za

https://orcid.org/0000-0002-5234-0555

(Received: 17 February 2019; accepted: 8 November 2019)

\section{Abstract}

In this conceptual paper, I argue that the decolonising curriculum project at a faculty of health sciences is not achieving the intended purpose of decolonisation, which is to engage alternative African knowledge frames within the programmes' curricula. In the race to respond to students' demand for the decolonisation of the university curriculum, in 2017 the faculty took a decision to focus on socio-economic determinants of health as an aspect of curriculum content that would serve the decolonising project. I contend that this approach does not constitute a decolonising project since there is no engagement with what ought to be an alternative African paradigm, in this case African healing as an alternative knowledge frame. Drawing on critical race theory (CRT) and the notion of critical performativity, I propose reclaiming the rightful place of African identities and knowledges by engaging critical performativity as a pragmatic and progressive pedagogical approach to explore African healing as an African indigenous knowledge system (IKS) in politically conscious and authentic ways.

Keywords: decolonisation, African indigenous knowledge, critical performativity, emancipatory, co-curriculum construction

\section{Introduction}

In this conceptual paper, I am concerned with the way in which a faculty of health sciences has undertaken the curriculum decolonising project. In the race to respond to students' demand for decolonisation of university curriculum and spaces, in 2017 the faculty took a decision to focus on socio-economic determinants of health as an aspect of curriculum content that would serve the decolonising project. I contend that this approach does not constitute a decolonising project since there is no engagement with what ought to be an alternative African paradigm, in this case African healing as an alternative knowledge frame. Instead, it is closing a long-standing curriculum gap that should be addressed separately 
outside of the decolonising project. An understanding of how social, economic, and environmental factors influence patients' health is necessary because it provides students with a knowledge base from which to treat patients in their individual contexts, thus improving opportunities for better health outcomes. However, considerate of the purpose of decolonisation - offering alternative African knowledges - such an approach is failing to redress the epistemic and cognitive injustice perpetuated by colonisation. Consequently, this paper responds to the Council on Higher Education's (CHE, 2017) call to rethink the project of decolonising the university curriculum not just to include what is taught but also how it is taught. Hence, from the perspective of critical race theory (CRT), I offer critical performativity as a pedagogical approach that could create emancipatory classroom settings for exploring alternative African knowledge frames. In this way, students together with academics could bring into classrooms their experiences and knowledge of African healing and begin to create authentically decolonising curriculum content. From this perspective-a consideration of the historical marginalisation of African indigenous knowledge systems (IKS) and a recognition that black people still hold this knowledge and continue to use it-it is necessary to begin by engaging a humanising pedagogy such as critical performativity in order to work towards the development of the content of an alternative curriculum.

The democratic era in South Africa created so-called free spaces for previously silenced and repressed people to raise their voices against the legacy of inequality and social injustice. However, 25 years into transformation, students in higher education realise that there is something fundamentally incomprehensible about a system that still permits colonised spaces and curricula. In reporting on students' experiences in these institutional settings, Mamdani (2016) noted,

For the black student in a historically white university, this made for an acutely alienating experience, leading the more perceptive of these students to call for a change in the content of the curriculum, one that would valorize the black ('native') experience, and not just relegate it to the domain of area studies. (p. 72)

Thus, during 2015/2016 students began their protests in the form of the Rhodes Must Fall campaign, "at the root of which was a fundamental questioning of the prevailing social and power relations and a legacy of inequality that students saw as not having been dealt with" (Council on Higher Education, 2017, p. 1).

Universities are being forced to shift from conceiving of decolonisation as an ideology to a pragmatic process that ought to achieve ideal social change. Since what the faculty thought of as its curriculum decolonisation decision, I have been grappling with what factors might have triggered this decision when after more than twenty years of democracy universities have not truly initiated the deconstruction and re-thinking of curricula from an African perspective. Several questions emerged: Is it a cautious approach to ease people into the process of decolonisation? What does it seek to achieve in relation to conscientising students about African perspectives on health and healing? Is it because of limited knowledge frames in relation to African paradigms within the discipline of health? Is it a deliberate disengagement with or rejection of African thinking? 
Against this background, I begin by reviewing the concept of decolonisation in universities and offer an argument for decolonising the mind in order to begin with sincere decolonisation of curricula. I then engage literature that addresses decolonisation of health sciences' education. To advance the argument for authentic decolonisation, I appeal to the precepts of CRT to highlight the bias to whiteness, which undermines the centring of blackness. This is followed by a brief examination of critical pedagogy as a framework within which critical education is premised. I do this to carve out a place for the relevance of critical performativity as a pedagogical tool in decolonising curricula and follow this with an exploration of critical performativity as a moderate view of critical management studies (CMS) that advances performative alternatives and extends it to a possible decolonising pedagogy.

\section{Decolonisation in universities}

South African student protests during 2015/2016 reflect McInerney's (2009, p. 24) position that, "[w]hen students have little power over their learning, when learning has little relevance to their lives and aspirations, or when they are devalued or marginalised, they are likely to engage in acts of resistance or withdraw their assent altogether from schooling." On the face of it, the \#RhodesMustFall and \#FeesMustFall protests paved the way for radically transforming the current socio-political trajectory of education curricula by rejecting the universalisation of Western knowledge systems. However, it has opened, fundamentally, an assortment of complex problems hidden within the fragile South African democracy where race still matters.

The conception of decolonisation is centred on rejecting colonisation by dismantling Eurocentric white supremacy domination. Mackinlay and Barney (2014) view decolonisation as a consciousness that contests the hegemonic singularity of Eurocentrism, an ethical position that fights for humanity and social justice for colonised people. Mamdani (2016) observes that decolonisation encompasses political, economic, and epistemological dimensions. The political dimension extends beyond just democratic rights to encompassing an extensive transformation of all organs of oppression and inequality. He asserted,

The economic understanding has also broadened from one of local ownership over local resources to the transformation of both internal and external institutions that sustain unequal colonial-type economic relations. The epistemological dimension of decolonization has focused on the categories with which we make, unmake and remake, and thereby apprehend, the world. It is intimately tied to our notions of what is human, what is particular and what is universal. (Mamdani 2016, p. 79)

The decolonisation task facing universities is complex since they are entangled in the double bind of the colonised curriculum and the burden of neoliberal performativity of knowledge production, which has capturing implications. Considerate of this challenge, Leibowitz (2017) averred that the notion of a decolonised currriculum is not a fragmented process, but should be a university wide project in which all stakeholders (leaders, managers, academics, 
students) work together to transform epistemologies underpinning academic disciplines. However, what underscores the challenge for universities and academics in decolonising curricula is ingrained white supremacy, the African inferiority complex described by Fanon, ([1952]1967) and enduring Africans' subjectification (Mungwini, 2016). As such, colonised psyches stand in the way of efforts to decolonise.

A decolonising project for universities means that they ought to confront the decolonising mandate through the probing of racially, politically, and historically misinformed epistemologies to enable a re-thinking of existing knowledge and the creation of new epistemologies (Maringe, 2017). Ngugi wa Thiongo (1981) is informative with his position that decolonisation is about centring Africa in curriculum in relation to content and to teaching and learning. It ought to be about Africans rediscovering themselves outside whiteness and about the repositioning of Africans in relation to others and the world at large. In view of the essence of decolonisation entailing the dismantling of dominant ideologies and the offering of an alternative, how do universities materialise decolonisation?

Garuba (2015) posits two possible ways to decolonise curricula. The first approach relates merely to augmenting current Eurocentric curricula with speckles of African content.

However, it is still a diluted approach that continues to serve the colonisation mandate. The second approach suggests a deep, reflexive strategy that starts with a critical interrogation of the forms and formations of the ideologies, discourses, and knowledges by which Africa and the African is constructed. This approach holds promise for authentic decolonisation since it points to a breaking of the yoke of colonisation that is founded on a singular worldview that offers Eurocentrism as the only measure of humanity.

In this view, a decolonised curriculum in South African universities ought to reflect a revelation, affirmation, and integration of Africans' beliefs, morals, and ways of thinking and doing (Heleta, 2016). Wa Thiong'o (1981) aptly argues that we cannot reach the apex of decolonisation until the colonising discourses that constructed the African's being, identity, language, culture, values, intellect, and socio-economic status have been deconstructed. Cognisant of the damaging consequences of colonialism's elevation of Western knowledge systems while disparaging African knowledges, as Heleta (2016) has pointed out, we are obliged to reclaim African IKS. To do this, we ought to raise an African consciousness (Nkoane, 2006). We could then be positioned to answer the question, "What does it mean to decolonise curriculum?" Taking inspiration from Soto (2014), we must note first that the Western paradigm's positivist notion of impartial, detached, unbiased knowledge continues to fail in making the world a better place.

The argument for articulating, embracing, and rooting African IKS in curricula, is simple. First, it is deeply entrenched in humanity, particularly in these existential times during which inhumanity is increasing. Second, the world is not homogenous. It is populated by people with varying beliefs, attitudes, and ways of being, all of which inform their interaction with their immediate world. Furthermore, in the context of my argument, the faculty could create the conditions of possibility to correct misconceptions about African healing, for example, 
the idea or belief that African healers or inyangas and sangomas are witchdoctors and that African healing is evil.

\section{Decolonising a health sciences curriculum}

The decision to include socio-economic determinants of health as a mode of decolonising curriculum was undertaken by the faculty's management committee (dean, vice-deans, and heads of departments). The faculty provides health education and training in the programmes of biomedical technology, chiropractic, complementary health, emergency medical care, environmental health, nursing, optometry, podiatry, radiography, and somatology. Socioeconomic determinants of health are the conditions under which people are born, live, and work, including their environmental circumstances that influence their health and wellbeing (World Health Organisation, WHO; 2018). They include economic status, quality of education, access to housing, transport, and health care services, along with a clean and safe environment. Given the huge impact of these factors on health equity, there have been growing calls within health sciences education to include these in the curriculum (Thornton $\&$ Persaud, 2018). Hence, the faculty determined that in the context of the South African health system that is struggling to provide an equitable and humanising healthcare, it is necessary to foster students' understanding of the influence of socio-economic determinants of health on health outcomes. It is unquestionable that such an understanding clarifies the context within which healthcare is delivered, and this could improve the provision of an effective holistic approach to health care.

The faculty engaged the services of experts in the field to offer workshops to help guide academics on integrating socio-economic determinants into disciplinary content. Of concern is that while the underpinning purpose was to decolonise, there was silence on the historical and political racial context of colonisation and the meanings of decolonisation of health sciences education. Pentecost, Gerber, Wainwright, and Cousins (2018, p. 225) raised similar concerns, when they noted that "health sciences curricula are stubbornly ahistorical. Apart from including such content for its educational value, integrating an historical and contemporary awareness is essential to fostering the critical lens required for practising in post-apartheid South Africa." Furthermore, the faculty did not interrogate the provision of health care training that would prepare students to offer just and equitable healthcare that recognises equally the value of biomedical and African healing approaches.

Founded on Western modes of thinking and practices, the health sciences curriculum excludes the role played by African beliefs, values, and practices, and the use of indigenous medicine in addressing health problems (Pillay \& Kathard, 2015). It is thus questionable that the inclusion of socio-economic determinants of health as a mode of decolonising a health sciences curriculum would begin to reverse the consequences of colonialism and apartheid when there is no mention of African healing that is practiced by more than $70 \%$ of black Africans. Pillay and Kathard (2015) cautioned against the depoliticisation of decolonising projects, contending that this is an attempt to maintain Western dominance. They argue "that only through strong political (re)conscientising in educational processes will we find new 
ways of being health professionals who take ownership of developing practices relevant to Africa" (p. 194).

Various studies have made a case for the decolonisation of health education curricula, offering frameworks and empirical evidence for authentic and meaningful curricula transformation. These studies emphasise the what and the how of decolonising health education curricula. In this vein, Pentecost et al. (2018, p. 221) have argued for an integrated framework "that includes and equally values the natural or biomedical sciences as well as humanities, arts and social sciences, respecting that all of this knowledge has value for the practice of healthcare." This curriculum encompasses questioning knowledge hierarchies and decolonising curricula, challenging the image of the health professional, and cultivating a social ethic. Similarly, Shizha and Charema (2011) have advocated for fostering a holistic approach to healthcare and wellbeing that encompasses biomedical and traditional healing approaches to ensure spiritual, mental, physical, and social healing. These approaches offer propositions for a transformed curriculum that is inclusive, humanising, and aligned to the reality of how the majority of South Africans experience healing and healthcare.

There is silence on how the decolonising project has been unfolding in the faculty because since 2018 the university has shifted towards the exploration of the Fourth Industrial Revolution. Academics work in their private disciplines to include socio-economic determinants of health in their modules. They have reported including these as an additional learning unit of a module. A checklist system is used to report on the progress thereof.

\section{Critical race theory: Decolonisation of the mind}

Perhaps our biggest challenge to date is to decolonize our minds. (Soto 2014, p. 317)

I believe the challenge to decolonise our minds lies in the slow pace at which South African universities have taken up the mandate to decolonise curricula. CRT is an appropriate framework within which to probe naturalised assumptions about racial differences that are impeding authentic decolonisation. CRT confronts present racialism hidden under notions of neutrality, objectivity, and colourblindness (Solórzano \& Yosso, 2002). It serves to dismantle both the white superiority complex and the African inferiority complex mentioned above. Racially conscious individuals, such as Steve Biko (2004), exposed the violence of colonisation and its active refusal of African identities, knowledges, and practices when he said, "The African child learns to hate his heritage in his days at school. So negative is the image of African society presented to him that he pretends to find solace in close identification with white society" (p. 194).

In a society where whiteness is normalised as a determinant of all that matters, I argue that decolonisation discussions are fundamentally a racial deconstruction. Based on the notion of white supremacy, black and white people are positioned dichotomously, with black people labelled as an inferior race and white people a superior one (Ladson-Billing, 1998). Such racial positioning accords privilege to whites and disempowers Africans. Hence, I argue that in the context of South African universities, CRT is a necessary framework to analyse and 
position racism in the decolonisation discourse and pedagogy in order to disrupt its hegemony. Colonisation and racialism are intertwined as technologies of power and oppression that require us to pose and explore difficult questions pertaining to the empowering and disempowering role of race in all aspects of our lives (Dei, 2008).

CRT addresses the politics of curriculum in education where that politics is owned by whites and which accords them power and authority over African people, dictating what they need to know and how (Ladson-Billings, 1998). It offers a basis from which to interrogate critically all education stakeholders' positions and conceptualisation of curricula decolonisation. CRT illuminates the embedded disadvantage of Africans as the othered in academic arenas and curriculum (Ladson-Billings, 1998). It accounts for the role of racism in how students and academics construct their identities and worldviews. A deconstruction of fallacious identities, which is an important criterion for decolonisation, can be possible when Africans take up a reflexive stance that posits an affirmed African with invaluable insights and commits these insights to rebuilding African dignity. Significant as well is Nakata's (2002) argument that decolonising projects will fail unless non-indigenous (white) academics also interrogate critically the paradigms that underpin their identity formations and social, political, and cultural positioning.

Odora-Hoppers and Richards (2011, p. 7) have reminded us that the coloniser colonises the mind "through disciplines, such as education, science, economics and law." Hence, I argue for the decolonisation of the mind. It has a rightful place in the genuine pursuit of social, cognitive, epistemic, and economic justice. Students and academics could be exposed to different possibilities of being and doing in classrooms. The question is: "How do we begin to do this in classrooms?" I contend that critical performativity through the CRT lens could give us a way into the minds and hearts of both students and academics to assist universities to begin a journey of the thinkable and the unthinkable and to find possibilities for a point of collusion between African and Eurocentric paradigms and epistemologies. In view of the marginalisation and silencing of black people's voices in academia and curricula, counterstorytelling is a viable CRT tool to use to confront the dominance of Western knowledge frames in curricula and allow black people to relate their experiences in their own voices. Counter-storytelling is "a method of telling the stories of those people whose experiences are not often told" (Solórzano \& Yosso, 2002, p. 26), thus it imbues authority on the voices of censored black people. From this perspective, counter-storytelling recognises the worth of black people's experiences in knowledge production and, in a classroom that aims to inspire co-curriculum construction with students, counter-story telling is significant. In the context of decolonising a health sciences curriculum, students' narratives of African healing could serve to counter or refute normalised narratives of Western healing. The critical performativity stance could create a safe zone in which students could offer rich narratives of their experience and knowledge of African healing. Moreover, these narratives could get us to realising what Shizha and Charema (2011) have described as the value of the co-existence of biomedical and African healing approaches where together they could enable authentically holistic healing that caters for the majority of the population. 


\section{From critical pedagogy to critical performativity}

A brief reflection on critical pedagogy is necessary to demonstrate my argument for critical performativity. Critical pedagogy lays a strong foundation for critical performativity by acknowledging that education is political. It is neither objective nor neutral (Freire, 1970). When we seek to transform education policies and practices, we take into account the enabling or disabling historical, socio-political, and economic conditions that influence education. Critical pedagogy is celebrated as a humanising pedagogy that re-writes students as agentic, knowledgeable, critically conscious active citizens (McInerney, 2009). Freire (1970) argued that traditional education is dehumanising because it objectifies students and constructs them as non-agentic entities who need to receive passively the knowledge delivered by teachers. To correct the injustice of what Freire (1970, p. 72) called "banking education," he offers "problem-posing education" that problematises and confronts world assumptions underlying content knowledge and classroom and societal relations. This approach is centred on students' awareness of their oppression, thereby inspiring an emancipatory frame of thinking (McInerney, 2009), which could radically reform classrooms into more democratic ones for deliberated and meaningful interactions (Breunig, 2010). Freire (1973) presents the notion of conscientisation as a reflexive approach that questions world assumptions that have normalised certain ways of thinking, of being, and of doing that reinforce domination and control. From this perspective, critical pedagogy is what the decolonising project calls for in order to facilitate the disruption of a colonised thinking. It is important for students to be empowered to probe independently repressive undemocratic political systems, and marginalising social and economic norms (Freire, 1973). Following Freire (1970), teachers ought to create a safe environment in which to affirm students' experiences and the accompanying knowledge as having been informed by their social and cultural background and use these as frames of reference for engaging with new knowledge.

Spicer, Alvesson, and Kärreman, (2009) have defined critical performativity as pragmatic emancipatory performances that destabilise repressive discourses and practices. Positioning critical performativity in education purposefully aligns it to critical pedagogy since it "seeks to engender spaces of intellectual openness and inquiry . . . it presents both negative and positive cases in a mutually informative exchange between students and instructors" (Fleming \& Banerjee 2016, p. 270). Spicer et al. (2009) proposed the notion of critical performativity in response to the critique that critical management studies (CMS) fail to offer a practical way out of repressive organisation conditions. It is conceptualised as an analytical framework that could extend CMS from just critique to critical performatives that bring about social change (Fleming \& Banerjee, 2016). Fundamental to the ethos of CMS is the critique of neoliberal performative cultures that exploit power asymmetries in organisations and society. It offers emancipatory alternative performatives that counter neoliberal performative cultures. Spicer et al. (2009, pp. 545-554) offered the following principles or tenets of critical performativity: affirmation, circumspect care, progressive pragmatism, presenting potentialities, and normative orientation. They propose critical performativity as a nonprescriptive approach, which in some way is open to exploration in unlimited ways. It therefore offers wide-ranging possibilities, particularly where institutional or societal change 
is an imperative, including classroom interactions (Contu, 2017). It is apparent that decolonising curricula would be an intricate project characterised by a multiplicity of ideas and positions. Hence, le Grange (2016, p. 6) has suggested that "the process should be embarked upon thoughtfully but [should] also be open to experimentation from which much could be learned." It is in this spirit that I see value in critical performativity to guide studentteacher classroom dialogue in disentangling colonisation, decolonisation, and African healing and reframing alternative paradigms in curricula.

I contend that critical performativity has the potential to facilitate critical education if we reimagine it as a pragmatic tool that could extend critical pedagogy. At its core, critical performativity aims to dismantle the normalised exploitation of power, which excludes and dehumanises those who do not possess it (Spicer et al., 2009); it offers an alternative to entrenched colonial and neoliberal thinking and practices that ground much of the meaning of education.

Critical performativity recognises that critique cannot be effective if it is articulated at a distance from the context under scrutiny (Spicer et al., 2009). Thus, its intent is to promote closer interaction with the people who experience discomforting discourses and practices. This will help gain deeper insight into that particular context so that the scholar and those in disempowering conditions can explore together, through critical dialogue and deliberation, alternative ways of thinking, speaking, and doing (Pillay \& Kathard, 2015). While critical performativity is conceptualised to engage actively with management in organisations to effect radical change (Spicer et al., 2009), it is well suited to the attainment of liberated and pragmatic curricula objectives (Dei, 2008) that can lead to alternative epistemologies. In using critical performativity for decolonising curricula, critical performativity calls upon academics to become intellectual activists (Contu, 2017) who facilitate closer, open, and critical interaction with students about their beliefs, knowledge, and experiences of their world, particularly their African knowledges. A disruption of the misconceptions about Africa, the African, and African healing and IKS ought to undergird this facilitation.

Wicket and Schaefer (2015) have offered progressive performativity as an additional dimension to critical performativity; this involves micro-engagements with those leaders who are seen as agents of change. It is a way of working progressively towards social renewal. In the context of South African universities, students are these agents of change since they spearhead the demand for decolonisation. They have to be engaged as the knowers and not as just as empty vessels to be filled with knowledge (Freire, 1970). By facilitating microengagements with an existing practiced African IKS, academics add momentum to a train that is already in motion. What matters is how the train tracks are cleared to permit of alternative paradigms. Reflexive conscientisation then becomes crucial because it stimulates students' awareness of their own colonised misconceptions that prejudice African knowledges and experiences.

In the next section, I examine how each of the critical performativity tenets could be engaged in working towards a co-construction of a decolonised curriculum. 


\section{Materialising decolonisation through critical performativity}

In materialising decolonisation, we ought to be moving from a non-constructive critique of a colonised curriculum to a critically productive position of affirming decolonisation as a politically imperative project and centering African IKS for national and global relevance. Spicer et al. (2016, p. 233) felt strongly about extending critical performativity in order to confront controversial public concerns for "a more critically performative approach" that consciously and pragmatically initiates change. The aim then is to reveal alternatives that are critically contemplated and openly negotiated. While it appears that decolonising curricula is just an education issue, from a transformational perspective it is of immense public interest in South Africa because it has implications for societal transformation and progression. The critical performativity tenets of affirmation, circumspect care, progressive pragmatism, presenting potentialities, and normative orientation could guide us in our interaction with students in classrooms when we are interrogating curricula decolonisation.

\section{Affirmation}

For informed critical enquiry, the tenet of affirmation inspires an acknowledgement of the phenomenon under scrutiny. It aims to achieve a deeper insight and a re-thinking of assumptions (Spicer et al., 2009), thereby identifying possibilities for reconsideration or alteration. In the decolonising endeavour, we critique colonisation as premised on Eurocentrism. We have to commit to understanding how Eurocentrism has managed to produce such persistent dominant thinking and culture after decades of supposed democracy in Africa. In this way, we can think of ways to undermine the stronghold of Eurocentrism.

In attempting to understand the object of critique, suspension of existing assumptions is vital to give those who experience them a fair opportunity to reveal their truths. It could also provide safe and meaningful opportunities for critique. From the position of decolonising curriculum, affirmation could promote the importance of acquiring knowledge about colonisation and understanding of how it affects white and black people psychologically, emotionally, physically, and spiritually. It lays the ground in illuminating the importance of a deep recognition of context and the way in which it undermines emancipation. This, in turn, could allow us to tease out enabling conditions for change. Affirmation taken as the premise for decolonisation encompasses academics listening carefully to, and being thoughtful about, students' views, how they experience university life, curricula, and classroom interactions. With this offering, affirmation is justifiable as a strategy to create an authentic setting that is rooted in accepting the truths and reality of others and according them the significance and respect they deserve.

Affirmation supports the recognition of difficult realities with which people struggle every day. In this way, it could support an understanding of the violence and humiliation of Africans as so-called inferior human beings, highlighting the need for respect and compassion. In view of black South Africans being rendered "invisible in the historiography 
of the country: an epistemic injustice" (Davids, 2017, p. 24), affirmation is imperative if they are to reclaim their dignity.

Engaging affirmation is not so much about getting the answers or concrete knowledge about African IKS. Rather, it is about exploring and clearing the minefield of experiences and knowledges that could be readily usable or not, allowing curiosity to take its course. At the same time, it could offer an opportunity to purge the pain and shame of Africans being those thought to have "deficit genes and culture" (Chillisa, 2012, p. 17).

\section{Circumspect care}

The tenet of circumspect care creates a safe environment in which peoples' views about their experiences can be voiced and heard, while, at the same time, be gently interrogated (Spicer et al., 2009). Decolonisation involves caring for students and giving them voice as participants on the fringes of decision-making about curricula. It fosters critical dialogue with students about their views and about how and why they have come to hold them. With circumspect care, academics can become aware of students' views, which also inform the types of questions they might ask. It offers students and academics an opportune time and ensured safety in which to ask difficult and uncomfortable questions. It could stimulate "reorientations that enable and engage alternative ways of knowing and require university students to deconstruct their own cultural situatedness in academia" (Williamson \& Dalal, 2007, p. 52). As Contu (2017) has suggested, academics require a great deal of sensitivity when they encourage students to question their assumptions, particularly when they could be presented with counter arguments.

Born into a world that distrusts Africa and its representation, university students are prone to being indoctrinated into the negative psyche about Africa. A level of sensitivity is imperative when they voice beliefs and values that reify Western thinking. It is common to hear students voicing doubt about and disregard for Africa. We need to expose a system that teaches youngsters that they are better and worthy only insofar as they are speaking and doing things the Western way. Affirmation and circumspect care could give students and academics points of consensus on aspects of decolonisation that could be exploited pragmatically within the discourses and practices of disciplines. This could lead to rediscovering African IKS applicable to current curricula and to identifying those that need further examination.

\section{Progressive pragmatism}

The tenet of progressive pragmatism focuses on specific issues and the practicality of possible change that is "progressive insofar as it helps to reduce harmful ideas, create less harmful alternatives and build spaces for deliberation" (Spicer et al., 2016, p. 236). Progressive pragmatism suggests being explicit about what needs to be achieved with decolonisation, that is, an African way of thinking that should be explicit and practical about discarding misconceptions about Africa and removing them from curricula. This also involves being cognisant of the possibility of discord (Spicer et al., 2009). However, it is important to identify avenues for micro-emancipations. With academics' and students' 
renewed critical consciousness, new practices could be talked into existence through the performative effects of language (Wickert \& Schaefer, 2015). This entails changing the terms in and through which subjects constitute identities within institutional subject positions (Spicer et al., 2016).

Progressive pragmatism could facilitate an exploration of what is currently in curricula, and provide the chance to re-think epistemology aimed at the greater good. We could search for common everyday traditional practices that we take for granted and make sense of them in relation to their purpose, without seeking evidence to prove them. These established practices have been passed down from generation to generation through storytelling and memory. Davids (2017, p. 93) has argued, aptly, "that epistemic marginalisation of historically oppressed communities can be ameliorated by employing 'emancipatory memory work'." African healing is already in place as an alternative healing system. More than $70 \%$ of Africans in South Africa use it (Hewson, 2015). A lot of work has been done in this area; it is readily available to be included in a health sciences curriculum. Wellness, when spirituality is included as a component of holistic health, is a case in point. However, an orthodox health sciences perspective does not recognise spirituality as being central to illness and health in every respect. In African healing, it is the essence of health and illness.

\section{Presenting potentialities}

Presenting potentialities relates to "creating a sense of what could be by engaging latent possibilities in an organization" (Spicer et al., 2009, p. 546). From a decolonising perspective, presenting potentialities involves transcending a critique of Eurocentric epistemologies in curricula to seek what is conceivable by exploring the hidden curricula potential in African IKS. African IKS are not bounded; they offer unlimited potential if we engage with them in an open and expectant way. By accepting that there are novel possibilities, we have to expand our thinking into the future (Spicer et al., 2009). From the decolonising position, it is about what it might mean to bring existent African IKS into curricula to respond to unanswered questions and work towards resolving current world dysfunctionalities and health-related problems such as the increased manifestation of obesity, autism, cancer, and so forth.

We could position African IKS in the future, where they become a point of reference for inspiration by exploring with students alternative ways of conceiving of their worlds. Hewson (2015) echoed the possibilities for the potential of IKS to provide solutions when she argued that "the knowledge, attitudes and skills of indigenous people might hold the answers, at least in part, to the world's current problems." She went on to say, "I also believe that until indigenous knowledge becomes a part of the curriculums in educational institutions, we will not be able to remediate the learning difficulties of non-westerners" (p. 4).

\section{Normative Orientation}

Normative orientation involves seeking ideals for good organisation practice by engaging micro-emancipations (Spicer et al., 2009). In the decolonising process, normative orientation 
encompasses determining criteria used to judge authentic, undiluted, and meaningful forms to decolonise curricula. In this sense, social, epistemic, cognitive, and economic justice issues and concerns should steer the criteria (Leibowitz, 2017). We need a free, deliberated, and negotiated place in which teachers and students can be vulnerable about their prejudiced or misinformed positionalities on knowledge that matters. To work towards such decolonising means that classrooms ought to be characterised by discourse and practice that are counterhegemonic, and that question established world assumptions, honour other ways of knowing, particularly African ways, and treat them and dominant ways of knowing equally. It also involves recognising social, political, cultural, and economic influences on knowledge content and its delivery. This will facilitate an awareness that for every knowledge taught, there is knowledge that is not taught. Furthermore, as Breunig (2010) has reminded us, classroom relations ought to be grounded in humaneness, affirmation, and respect for African students' identity and experience.

\section{Conclusion}

In this paper, I contend that the faculty of health science's inclusion of socio-economic determinants of health as decolonising curriculum content is not a decolonising project since there is no engagement with what ought to be an alternative African paradigm, in this case African healing, as an alternative knowledge frame. I am thus concerned with the need for universities and academics alike to question and rethink the wrong mind-set that underscores what are seen to be attempts to decolonise institutions and themselves but that ignore the imperative of decolonising the mind.

Within the CRT framing and counter-storytelling, I am proposing critical performativity through its tenets of affirmation, circumspect care, progressive pragmatism, presenting potentialities and normative orientation, as a decolonising pedagogy. In doing this, I am taking up the challenge to enact and support the decolonising project as both an epistemic and social justice issue. Within the decolonising project, critical performativity could achieve humanising social transformation through a pragmatically useful exploration of theories and practices underpinning the current colonised curricula and those informed by African perspectives. In facilitating Africans and others to understand the false premise of white supremacy, critical performativity could transform subordinate relations into equal ones.

Since critical performativity is primarily reflexive, it could enable the interrogation of unquestioned assumptions that form the basis of curriculum development and delivery. When critical performativity criteria are upheld, classroom performances do not reinforce subjugating knowledges, values, and beliefs. In cultivating reflexivity, critical performativity offers possibilities for mysteries to emerge from an extended, critical, and positive exploration of African IKS. At the same time, such mysteries could be constructed when we confront the tensions between African and Western discourses and re-think African IKS to answer unanswered modern-day questions or to solve current complex global health problems. 
Critical performativity could create opportunities for the location of African people and their work in university curricula and incite a positive re-articulation of the African paradigm, thereby debunking black people's inferiority complex and the related subordinated knowledges. It could be a useful means of strengthening students' and academics' intellectual argumentation for decolonisation because it permits a start from a position of comprehensive engagement with colonisation. It is to be hoped that this will address the deliberate ignorance on which the colonised mind-set is based.

Critical performativity as a possible pedagogical method gives credence to the coconstruction of curricula with students and offers a practical and constructive approach that academics could explore when they are engaging in discussions on decolonisation in their disciplinary arenas. Classrooms could be spaces for unprejudiced intellectual interaction and critical interrogation in a democratic atmosphere of possibility, excitement, love, and compassion where students' narratives of African healing could counter narratives of Western healing. However, I recognise that empirical studies are necessary to determine how critical performativity can be useful as a decolonising pedagogy. To this end, this conceptual paper is a mere discursive act intended to stimulate useful debate and, ultimately, to promote empirical studies that could determine its value-add.

\section{References}

Biko, S. (2004). I write what I like: Selected writings. Johannesburg, RSA: Picador Africa.

Breunig, M. (2010). Teaching for and about critical pedagogy in the post-secondary classroom. Studies in Social Justice, 3(2), 247-262. https://doi.org/10.26522/ssj.v3i2.1018

Chilisa, B. (2012). Indigenous research methodologies. Los Angeles, CA: SAGE.

Contu, A. (2017). “. . . The point is to change it" - Yes, but in what direction and how? Intellectual activism as a way of "walking the talk" of critical work in Business Schools. Organization, 25(2), 282-293. https://doi.org/10.1177/1350508417740589

Council on Higher Education. (2017). Briefly speaking: Decolonising the curriculum: Stimulating debate. Retrieved from https://www.che.ac.za/sites/default/files/publications/BrieflySpeaking\%20(3)\%20Cur riculum\%20decolonisation.pdf.

Davids, M. C. (2017). Using memory work as a decolonising pedagogy in a study on District Six's forced removal history: A case for epistemic justice. Journal of Education, 69, 93-116. Retrieved from http://www.scielo.org.za/scielo.php?script=sci_arttext\&pid=S252098682017000200005 
Dei, G. S. (2008). Indigenous knowledge studies and the next generation: Pedagogical possibilities for anti-colonial education. Australian Journal of Indigenous Studies Supplement, 37S, 5-13. https://doi.org/10.1375/S1326011100000326

Fanon, F. ([1952]1967). Black skin white masks. (C. Markmann, Trans.) New York, NY: Grove Press.

Fleming P., \& Banerjee B. (2016). When performativity fails: Implications for critical management studies. Human Relations, 69(2), 257-276. https://doi. org/10.1177/0018726715599241

Freire, P. (1970). Pedagogy of the Oppressed. London, UK: Penguin.

Freire, P. (1973). Education for Critical Consciousness. New York, NY: The Seabury Press.

Garuba, H. (2015, April 17). What is an African curriculum? Mail \& Guardian. Retrieved from http://mg.co.za/article/2015-04-17-what-is-an-african-curriculum/

Heleta, S. (2016). Decolonisation of higher education: Dismantling epistemic violence and Eurocentrism in South Africa. Transformation in Higher Education, 1(1), 1-8. https://doi.org/10.4102/the.v1i1.9

Hewson, M. (2015). Embracing indigenous knowledge in science and medical teaching. New York, NY: Springer.

Ladson-Billings, G. (1998). Just what is critical race theory and what's it doing in a nice field like education? International Journal of Qualitative Studies in Education, 11(1), 724. https://doi: 10.1080/095183998236863

Leibowitz, B. (2017). Cognitive justice and the higher education curriculum. Journal of Education, 68, 93-112. Retrieved from http://www.scielo.org.za/scielo.php?script=sci_arttext\&pid=S252098682017000100006

Le Grange, L. (2016). Decolonising curriculum. South African Journal of Higher Education, 30(2), 1-12. https://doi.org/10.20853/30-2-709

Mackinlay, E., \& Barney, K. (2014). Unknown and unknowing possibilities: Transformative learning, social justice, and decolonising pedagogy in indigenous Australian studies. Journal of Transformative Education, 12(1), 54-73. https://doi.org/10.1177/1541344614541170

Mamdani, M. (2016). Between the public intellectual and the scholar: Decolonization and some post-independence initiatives in African higher education. Inter-Asia Cultural Studies, 17(1), 68-83. https://doi.org/10.1177/1541344614541170 
Maringe, F. (2017). Transforming knowledge production systems in the new African University. In M. Cross. \& A. Ndofirepi (Eds.), Knowledge and change in the African universities (Vol. 2). Re-imagining the terrain (pp. 1-18). Rotterdam, NL: Sense Publishers.

McInerney, P. (2009). Toward a critical pedagogy of engagement for alienated youth: Insights from Freire and school-based research. Critical Studies in Education, 50(1), 23-35. https://doi.org/10.1080/17508480802526637

Mungwini, P. (2016). The question of recentring Africa: Thoughts and issues from the Global South. South African Journal of Philosophy, 35(4), 523-536. https://doi.org/10.1080/02580136.2016.1245554

Nakata, M. (2002). Indigenous Knowledge and the cultural interface: Underlying issues at the intersection of knowledge and information systems. IFLA Journal, 28, 281-291. https://doi.org/10.1177/034003520202800513

Nkoane, M. N. (2006). The Africanisation of the university in Africa. Alternation, 13(1), 4969. Retrieved from https://journals.co.za/content/alt/13/1/AJA10231757_546

Odora-Hoppers, C., \& Richards, H. (2011). Rethinking thinking: Modernity's “other” and the transformation of the university. Pretoria, RSA: Unisa Press.

Pentecost, M., Gerber, B., Wainwright, M., \& Cousins, T. (2018). Critical orientations for humanising health sciences education in South Africa. Medical Humanities, 44, $221-$ 229. https://doi.org/10.1136/medhum-2018-011472

Pillay, M., \& Kathard, H. (2015). Decolonizing health professionals' education: Audiology \& speech therapy in South Africa. African Journal of Rhetoric, 7(1), 193-227. Retrieved from https://journals.co.za/content/aar_rhetoric/7/1/EJC172807

Shizha, E., \& Charema, J. (2011). Health and wellness in Southern Africa: Incorporating indigenous and western healing practices. International Journal of Psychology and Counselling, 3(9), 167-175. https://doi.org/10.5897/IJPC10.030

Solórzano, D., \& Yosso, T. (2002). Critical race methodology: Counter storytelling as an analytical framework for education research. Qualitative Inquiry, 8(1), 23-44. https://doi.org/10.1177/107780040200800103

Soto, L. (2014). Projects from the heart: For educational leaders. In I. Bogotch \& C. Shields (Eds.), International handbook of educational leadership and social (in)justice (pp. 309-320). London, UK: Springer.

Spicer A., Alvesson M., \& Kärreman, D. (2009). Critical performativity: The unfinished business of critical management studies. Human Relations, 62(4), 537-560. https://doi.org/10.1177/0018726708101984 
Spicer, A., Alvesson, M., \& Kärreman, D. (2016). Extending critical performativity. Human Relations, 69(2), 225-249. https://doi.org/10.1177/0018726715614073

Thornton, M., \& Persaud, S. (2018). Preparing today's nurses: Social determinants of health and nursing education. The Online Journal of Issues in Nursing, 23(3). https://doi.org/10.3912/OJIN Retrieved from http:// ojin.nursingworld.org/Vol-232018/No3- Sept-2018/Social-Determinants-of-Health-Nursing-Education.

Wa Thiong'o, N. (1981). Decolonising the mind: The politics of language in African literature. Nairobi, KE: East African Educational.

Wickert, C., \& Schaefer, S. M. (2015). Towards a progressive understanding of performativity in critical management studies. Human Relations, 68(1), 107-130. https://doi.org/10.1177/0018726713519279

Williamson, J., \& Dalal, P. (2007). Indigenising the curriculum or negotiating the tensions at the cultural interface? Embedding Indigenous perspectives and pedagogies in a university curriculum. The Australian Journal of Indigenous Education, 36, 51-58. https://doi.org/10.1017/S1326011100004701

World Health Organization. (2018). About social determinants of health. Retrieved from http://www.who.int/social_determinants/sdh_definition/en/ 